\title{
PHENOLIC COMPOSITION AND BIOACTIVE PROPERTIES OF CELL WALL PREPARATIONS AND WHOLE GRAINS OF SELECTED CEREALS AND \\ LEGUMES
}

Short title: BIOACTIVES OF CEREAL AND LEGUME CELL WALLS

SULE O. SALAWU ${ }^{1,3}$, MEGAN J. BESTER ${ }^{2}$ AND KWAKU G. DUODU ${ }^{1 *}$

\author{
${ }^{1}$ Department of Food Science, ${ }^{2}$ Department of Anatomy \\ University of Pretoria, Private Bag X20, Hatfield 0028, South Africa \\ ${ }^{3}$ Department of Biochemistry, Federal University of Technology, P.M.B. 704, Akure, Nigeria \\ "Corresponding Author: Kwaku G. Duodu \\ Email: gyebi.duodu@up.ac.za \\ Fax: +27-12-420-2839
}

\begin{abstract}
Phenolic compounds are associated with cell walls in cereals and legumes. Phenolic composition and bioactive properties of cell walls and whole grain of sorghum, teff and cowpea was determined. Whole grain extracts had higher total phenolic content (630-2782 $\mathrm{mg} \mathrm{CE} / \mathrm{g})$ and total flavonoid content (0.033-0.17 mg CE/g) than cell wall extracts (261-1005 mg CE/g and 0.011-0.047 mg CE/g respectively). Similar trends were observed for ABTS radical scavenging (whole grain: 30-87; cell wall: $22 \mu \mathrm{M}$ TE/g), ORAC (whole grain: 47964; cell wall: 40-183 $\mu \mathrm{M} \mathrm{TE} / \mathrm{g}$ ) and ferric reducing power (whole grain: 85-279; cell wall:
\end{abstract}


41-95 mg vitamin C equivalent/ g). Whole grains contained both phenolic acids and flavonoids. Ferulic acid was a major component of cell walls. Whole grain and cell wall extracts inhibited LDL oxidation and protected against oxidative DNA damage. Cereal and legume cell walls may be considered important potential contributors to human health due to their phenolic composition.

Keywords: Cereals, legumes, cell wall preparations, phenolic compounds; antioxidant activity, LDL oxidation, DNA damage

\section{PRACTICAL APPLICATION}

Phenolic compounds in cereals and legumes are important components of dietary fibre in which they occur mainly in association with cell wall components. There is increasing research focus on phenolic compounds due to their bioactive properties and potential health benefits. Investigation of the cell wall bound phenolic compounds is necessary to establish their potential contribution to human health. In this study, the phenolic composition and antioxidant activities of extracts from cell wall preparations and whole grain of selected cereals and legumes of importance in Africa, as well as their protective effect on oxidized DNA damage and copper catalyzed LDL oxidation was determined. This research provides insight into the potential health benefits offered by the grains studied, such as prevention of chronic diseases of lifestyle and the importance of the bioactive phenolic constituents of cell walls in this regard.

\section{INTRODUCTION}

Cereal and legume grains are major sources of calories and proteins for a large proportion of the world's population (National Academy of Science, 1975). In terms of quantity, cereals occupy the first place as sources of calories and proteins, and grain legumes are the next 
(Salunkhe, 1982). In Africa, cereals (e.g. maize, millet, sorghum, teff) and legumes (e.g. soybean, groundnut, and cowpea) are important food crops.

Cereals are extremely versatile foodstuffs and are processed into a very wide range of traditional food and beverage products (National Research Council, 1996). In most African countries, cereals such as sorghum are processed into food and beverages which are important sources of nutrients. These include whole grain rice-type products, breads and pancakes, dumplings and couscous, porridges, gruels, opaque and cloudy beers, and nonalcoholic fermented beverages (Taylor \& Dewar, 2000). In Ethiopia, teff (Eragrostis teff) is made into injera, a flat, spongy, and slightly sour bread that looks like a giant bubbly pancake the size of a serving tray (Bultosa, Hall \& Taylor, 2002). Legumes such as cowpeas are an important part of the human diet in developing countries and are incorporated into a variety of local foods, weaning foods and snacks in Africa (Giami, 2005). Cowpea is consumed in many forms. Young leaves, green pods and green seeds are used as vegetables whereas dry seeds are used in a variety of food preparations (Nielsen et al., 1997).

In addition to dietary fiber, cereals and legumes contain many health-promoting components such as vitamins, minerals, and phytochemicals which include phenolic compounds. Phenolic compounds are well-known antioxidants and are hypothesized to have the potential to protect against degenerative diseases (heart diseases and cancer) in which reactive oxygen species are involved (Harbone \& Williams, 2000). Phenolic compounds in cereals and legumes may be classified in simple terms into phenolic acids (derivatives of benzoic acid or cinnamic acid), flavonoids and tannins. It is also well-known that the phenolic acids in particular may be present in free, esterified/etherified or insoluble bound forms (Salunkhe, 1982; Robbins, 2003). 
Endosperm and pericarp cell walls constitute the predominant components of dietary fibre which is the indigestible fraction of cereal and legume foods after passage through the gastrointestinal tract. The cell walls are mainly composed of non-starch polysaccharides (such as cellulose and hemicelluloses) and lignin. Hydroxycinnamic acids such as ferulic acid and pcoumaric acid may be bound to hemicelluloses (such as arabinoxylans and xyloglucans) in the cell wall. Although not yet reported in cereals or legumes, the presence of some cell wallbound flavonoids has been reported in other plants (Ibrahim et al., 1987). The association of phenolic compounds with cell wall components is of significance for foods rich in dietary fibre. If released and absorbed, these phenolics could offer potential health benefits. The presence of esterases in the mammalian intestinal tract that are active towards dietary hydroxycinnamates and the release of such esterified hydroxycinnamates has been reported (Kroon et al., 1997). Phenolic compounds bound to dietary fibre have been shown to have health beneficial effects (Vitaglione et al., 2008). Cell walls of cereals and legumes may thus be considered important potential contributors to human health. Therefore this work seeks to identify the phenolic compounds in cell wall preparations from selected cereals and legumes and their bioactive properties.

\section{MATERIALS AND METHODS}

\subsection{Materials}

Two sorghum types (white and red), two teff types (white and brown) and two cowpea varieties (Betchuana white and black-eyed pea) were used in this work. The two sorghum types were from the 2009 season and obtained from Free State Malt, Sasolburg, South Africa. The teff grains (2009 season) were obtained from PANNAR, Kroonstad, South Africa. The two cowpea varieties (2009 season) were obtained from Agricol, Potchefstroom, South Africa. 


\subsubsection{Preparation of whole grain flour}

The grains were milled into flour using a laboratory hammer mill (Falling Number 3100, Huddinge, Sweden) fitted with a $500 \mu \mathrm{m}$ opening screen and kept in sealed air-tight polythene bags prior to analyses.

\subsubsection{Preparation of cell wall material}

Cell wall material was prepared from the milled grains of sorghum, teff and cowpea using a modification of the method of Brillouet and Carre (1983). Milled grain (100 g) was sequentially extracted by magnetic stirring with n-hexane (300 ml; $2 \mathrm{~h})$, methanol (300 ml; 1

h) and acetone $(300 \mathrm{ml} ; 1 \mathrm{~h})$. The defatted seed meal was then soaked in $980 \mathrm{ml} 0.1 \mathrm{M}$ phosphate buffer, $\mathrm{pH}$ 6.5. The suspension was homogenized for $2 \mathrm{~min}$ and transferred into a water bath maintained at $60^{\circ} \mathrm{C}$. Proteolysis was conducted by incubating the suspension with a protease enzyme (Neutrase ${ }^{\circledR}$, Novozymes, Johannesburg, South Africa) at a concentration of $250 \mathrm{mg}$ per $20 \mathrm{ml} \mathrm{0.1} \mathrm{M} \mathrm{phosphate} \mathrm{buffer} \mathrm{(} \mathrm{pH} \mathrm{6.5)} \mathrm{with} \mathrm{continuous} \mathrm{stirring.} \mathrm{After} 20 \mathrm{~h}$, the suspension was centrifuged, re-suspended in phosphate buffer as before and retreated with $125 \mathrm{mg}$ Neutrase ${ }^{\circledR}$ for $4 \mathrm{~h}$. The white de-proteinized residue was recovered by centrifugation, copiously washed with water and air-dried. The protease-treated sample was suspended with violent stirring in 2 liters distilled water at $90^{\circ} \mathrm{C}$ and starch gelatinization was allowed to proceed for $10 \mathrm{~min}$. Then the temperature of the viscous suspension was rapidly adjusted to $85^{\circ} \mathrm{C}$ and $500 \mathrm{ml} 0.1 \mathrm{M}$ sodium acetate buffer $\mathrm{pH} 6.5$ was added. Starch hydrolysis was conducted by incubating the suspension with $\alpha$-amylase (Termamyl ${ }^{\circ}$ SC, Novozymes, Johannesburg, South Africa) at a concentration of $150 \mathrm{mg}$ per $25 \mathrm{ml} 0.02 \mathrm{M}$ sodium acetate buffer ( $\mathrm{pH}$ 6.5) with continuous stirring. After $2 \mathrm{~h}$, the suspension was centrifuged, the pellet re-suspended in acetate buffer as before and re-treated with $75 \mathrm{mg} \alpha$-amylase. The white deproteinized and de-starched residue (cell wall preparation) was recovered by centrifugation, 
thoroughly washed with water, freeze dried and stored in a vacuum-packaged polyethylene bag at $4^{\circ} \mathrm{C}$ prior to analyses.

\subsubsection{Preparation of extracts from whole grain flour and cell wall preparations}

Whole grain flour samples of each grain $(0.3 \mathrm{~g})$ were extracted with $30 \mathrm{ml}$ acidified methanol ( $1 \%$ conc. $\mathrm{HCl}$ in methanol) in three phases as follows: $10 \mathrm{ml}$ solvent was added to the flour sample in a conical flask and completely covered with aluminium foil. The sample was stirred magnetically for $2 \mathrm{~h}$, centrifuged in a $40 \mathrm{ml}$ plastic centrifuge tube at $1900 \mathrm{x}$ g for 10 $\min \left(25^{\circ} \mathrm{C}\right)$ and decanted, keeping the supernatant. The residue was re-suspended in $10 \mathrm{ml}$ of the solvent, stirred for $20 \mathrm{~min}$, centrifuged and decanted, keeping the supernatant and this process was repeated a third time. The supernatants were combined and stored in a glass bottle covered with aluminium foil and kept in a cold room at $4^{\circ} \mathrm{C}$ before analysis.

Extracts from the cell wall preparations were prepared using the method of De Ascensao and Dubery (2003). Dry cell wall preparation of each sample $(10 \mathrm{mg})$ was suspended in $1 \mathrm{ml} 0.5$ $\mathrm{M} \mathrm{NaOH}$ for $1 \mathrm{~h}$ at $96^{\circ} \mathrm{C}$. Under these mild saponification conditions, wall-esterified phenolics are hydrolyzed and released (Campbell \& Ellis, 1992). The suspension was acidified to $\mathrm{pH} 2$ with $1 \mathrm{M} \mathrm{HCl}$, centrifuged at $12000 \mathrm{x}$ g for $10 \mathrm{~min}$ and the supernatant extracted with $1 \mathrm{ml}$ anhydrous diethyl ether. The diethyl ether extract was reduced to dryness under vacuum with a rotary evaporator and the precipitate re-suspended in $0.25 \mathrm{ml} 50 \%$ aqueous methanol. The resulting solution was kept in a cold room at $4{ }^{\circ} \mathrm{C}$ before analyses. 


\subsection{Methods}

\subsubsection{Scanning electron microscopy}

The whole grain flour and cell wall preparations were mounted on double sided carbon tape on a stub; sputter coated with gold and subsequently viewed using a JEOL-JSM 840 (JEOL, Tokyo, Japan) scanning electron microscope.

\subsubsection{Determination of total phenolic content}

The total phenolic content of the methanolic extracts was determined by the Folin-Ciocalteu assay (Singleton \& Rossi, 1965). The methanolic extract $(0.25 \mathrm{ml})$ was reacted with Folin-

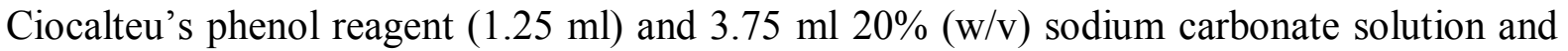
absorbance was read at $760 \mathrm{~nm}$ after $2 \mathrm{~h}$. Catechin was used as a standard.

\subsubsection{Determination of total flavonoid content}

Total flavonoid content was determined using a modified aluminium chloride colorimetric assay (Zhishen et al., 1999). Aliquots $(10 \mu \mathrm{l})$ of $0.01 \mathrm{~g} / \mathrm{ml}$ preparations of the extracts were added to 96 well microplates. To the wells, $30 \mu 12.5 \%$ sodium nitrite, $20 \mu 12.5 \%$ aluminum chloride and $100 \mu 12 \%$ sodium hydroxide were added. The solutions were mixed well and then read at $450 \mathrm{~nm}$ with a plate reader (Bio Tek). Catechin was used as a standard.

\subsubsection{HPLC analysis of phenolic compounds}

Analyses were performed using a Waters 1525 binary HPLC pump and a Waters 2487 dual wavelength absorbance detector (Waters Corporation, Milford, MA, USA). The separation was accomplished by means of a YMC-Pack ODS AM-303 (250 mm x $4.6 \mathrm{~mm}$ i.d., $5 \mu \mathrm{m}$

particle size) column (Waters Corporation, Milford, MA, USA). Breeze ${ }^{\mathrm{TM}}$ software was used to monitor the separation process and after analysis a chromatogram was obtained for each 
sample extract. The injection volume for all samples was $20 \mu \mathrm{l}$ with the analysis conducted at a flow rate of $0.8 \mathrm{ml} / \mathrm{min}$ and monitored at $280 \mathrm{~nm}$ and $330 \mathrm{~nm}$. The mobile phase consisted of $0.1 \%$ glacial acetic acid in water (solvent $\mathrm{A}$ ) and $0.1 \%$ glacial acetic acid in acetonitrile (solvent B). The linear gradient of the solvents was as follows: solvent B was increased from 8 to $10 \%$ in $2 \mathrm{~min}$, then increased to $30 \%$ in $25 \mathrm{~min}$, followed by an increase to $90 \%$ in 23 min, then increased to $100 \%$ in $2 \mathrm{~min}$, kept at $100 \%$ of B for $5 \mathrm{~min}$, and returned to the initial condition. Running time was $61 \mathrm{~min}$ and the column temperature was held at $25{ }^{\circ} \mathrm{C}$ during the run. Quantification of phenolics was conducted by using pure external standards of phenolic acids (ferulic acid, $p$-coumaric acid, syringic acid, vanillic acid, protocatechuic acid, caffeic acid, sinapic acid and gallic acid) and flavonoids (luteolin, rutin, naringenin, quercetin, catechin, taxifolin and kaempferol). Calibration curves were obtained for each phenolic compound by plotting peak areas versus concentration. Regression equations that showed high degree of linearity $(>0.995)$ were obtained for each phenolic compound from the calibration curves.

\subsubsection{ABTS antiradical assay}

Antioxidant activity of the extracts was determined using the ABTS antiradical assay (Awika et al., 2003) which involves determination of the decrease in absorbance due to decolorization of the blue-green $\mathrm{ABTS}^{\circ+}$ radical cation solution when reacted with the extracts or Trolox standard solution. The absorbance of the standards and samples was measured at $734 \mathrm{~nm}$. The results were expressed as $\mu \mathrm{M}$ Trolox equivalents/g sample, on dry weight basis. 


\subsubsection{Ferric reducing antioxidant power}

The reducing power of the extracts was determined by assessing the ability of the extract to reduce $\mathrm{FeCl}_{3}$ solution as described by Oyaizu (1986) and expressed as mg ascorbic acid equivalent/100 g sample, on dry weight basis.

\subsubsection{Oxygen Radical Absorption Capacity (ORAC) Assay}

The ORAC assay was carried out on a Fluorostar Optima plate reader (BMG Lab Technologies, Offenburg, Germany). Procedures were based on a modified method of Ou et al. (2002). AAPH was used as a peroxyl radical generator, Trolox as standard and fluorescein as a fluorescent probe. The final ORAC values of the samples were calculated by using the net area under the decay curves (AUC). The results were expressed as $\mu$ mol Trolox equivalent per g sample.

\subsubsection{LDL oxidation assay}

The ability of the extracts to protect against LDL oxidation was determined spectrophotometrically by measuring the amount of thiobarbituric acid reactive substances (TBARS) produced after $\mathrm{Cu}^{2+}$-induced oxidation of LDL in the presence of the extracts as described by Shelembe et al. (2012).

\subsubsection{Oxidative DNA damage assay}

The ability of the extracts to protect against oxidative DNA damage was determined using a modified form of the method of Wei et al. (2006). Plasmid DNA was incubated at $37^{\circ} \mathrm{C}$ for 30 min with $5 \mu 1$ of appropriate dilution of the methanolic extracts in the presence of 0.03 $\mathrm{g} / \mathrm{ml} \mathrm{AAPH} \mathrm{(for} \mathrm{extracts} \mathrm{from} \mathrm{cell} \mathrm{wall} \mathrm{preparations)} \mathrm{and} 0.0003 \mathrm{~g} / \mathrm{ml} \mathrm{AAPH} \mathrm{(for} \mathrm{extracts}$ from whole grain flour). Samples was loaded with $5 \mu$ loading buffer $(0.13 \%$ bromophenol 
blue and $40 \% \mathrm{w} / \mathrm{v}$ sucrose) onto a $1 \%$ agarose gel containing ethidium bromide. The gel was then run for $3 \mathrm{~h}$ at 30 Amps and 55 Volts. The gels were photographed under UV light. DNA strand breaks were evaluated using the untreated DNA under the same incubation condition as a control and analyzed using Image Tool version 3.0.

\subsubsection{Statistical analysis}

The experiment was conducted in duplicate and analyses for antioxidant activity, other bioactive properties and HPLC phenolic composition were run in triplicate. Mean values and standard deviations were calculated using Microsoft Excel software (Microsoft Corporation, Redmond, WA). One-way analysis of variance (ANOVA) was conducted and differences between means were considered significant at $\mathrm{p}<0.05$ using the least significant difference (LSD) test.

\section{RESULTS AND DISCUSSION}

The scanning electron micrographs of the whole grain flours and cell wall preparations of the selected cereals and legumes are shown in Figure 1 (A-L). The micrographs of the whole grain flour samples (Figure $1 \mathrm{~A}, \mathrm{C}, \mathrm{E}, \mathrm{G}, \mathrm{I}$ and $\mathrm{K}$ ) revealed the presence of small chunks of material (labelled 1), possibly created as a result of the milling process. These chunks appeared to consist of starch granules clumped together, however protein bodies were not clearly visible. The micrographs of the cell wall preparations of brown teff (Figure 1B), white sorghum (Figure 1D) and white teff (Figure 1F) revealed the presence of fragments of cell wall material (labelled 2). There were also many small particles (labelled 3) which are likely to be remnants of starch granules and protein bodies after the enzymatic hydrolytic process. Red sorghum (Figure 1H), black eyed cowpea (Figure 1J) and Betchuana white cowpea (Figure 1L) cell wall preparations showed the presence of chunks of material (labelled 4) which seemed to consist of empty cells. This is perhaps due to the removal of the cell wall 
contents by enzymatic hydrolysis, thus leaving the empty cells with cell walls exposed. Overall, the micrographs show that the cell wall preparation process reduced protein and starch to a large extent to produce cell wall-enriched preparations.

The total phenolic and the total flavonoid content of the whole grain flours and cell wall preparations are shown in Figure 2. In general, cell wall preparations had lower total phenolic content compared with the corresponding whole grain flours (Figure 2A). For the whole grain flours, Betchuana white cowpea had the highest total phenolic content followed by red sorghum with white sorghum having the lowest total phenolic content. Of the cell wall preparations, that from red sorghum had the highest total phenolic content while that from black-eyed cowpea had the lowest.

The higher total phenolic content of the red sorghum whole flour compared to white sorghum is in agreement with Dlamini et al. (2007) who also reported higher total phenolic content of red sorghum whole grain compared to the white type. Generally, pigmented sorghums (with red and purple colour) have higher total phenolic contents than white, tan plant sorghums (Dykes \& Rooney, 2006). However, the effect of grain pigmentation on total phenolic content as observed for the red and white sorghum was not evident with the teff samples as there was no significant difference in the total phenolic content of brown and white teff whole grain (Figure 2). The high total phenolic content of Betchuana white cowpea compared with black eyed cowpea could also be probably due to the pigmented nature of Betchuana white seed coat. The observed higher total phenolic content in the whole grain flour samples compared to the corresponding cell wall preparations could be due to the presence of other phenolic compounds such as flavonoids in addition to phenolic acids. Unlike the whole grain, 
phenolics in the cell wall tend to consist essentially of hydroxycinnamic acid derivatives such as ferulic acid and p-coumaric acid (Kamisaka et al., 2006).

The highest total flavonoid content was recorded for Betchuana white cowpea followed by red sorghum, while much lower values were recorded for white sorghum, brown teff, white teff and black eyed cowpea (Figure 2B). In general, whole grain flours tended to have higher total flavonoid contents than the corresponding cell wall preparations. This observation would be expected since as mentioned earlier, cell walls of grains are mainly composed of hydroxycinnamates. In addition, flavonoids in other parts of the grain may have been lost during cell wall preparation. However, the presence of some cell wall-bound flavonoids has been reported in other plants (Ibrahim et al., 1987).

Figure 3 shows the HPLC profiles of the extracts from whole grain flours and cell wall preparations. More peaks attributable to flavonoids could be identified in extracts from whole grain flours compared to extracts from cell wall preparations. The phenolic acid and flavonoid contents of the extracts from whole grain flours and cell wall preparations as identified by HPLC are shown in Table 1. The cell wall preparations from red sorghum, white sorghum and the two cowpea samples contained p-coumaric acid and ferulic acid as their major phenolic compounds (Table 1, Figure 3). Cinnamic acid derivatives such as pcoumaric and ferulic acids are known to be important components of cell walls of cereals where they occur in bound form to polymers of the wall (Kamisaka et al., 2006). In contrast, the cell wall preparations of the teff samples and Betchuana white cowpea contained in addition to the hydroxycinnamic acids, some flavonoids (luteolin and quercetin for teff samples and catechin for Betchuana white). The presence of some cell wall-bound flavonoids in other plants has been previously documented (Ibrahim et al., 1987). For the whole grain flour samples the flavonoids catechin and apigenin (red sorghum); apigenin (white sorghum) 
and quercetin (black eyed pea) (Table 1) occurred in higher quantities compared to other identified flavonoids. Overall, most flavonoids identified in the whole grain flour were not detected in the cell wall preparation. This is an indication that flavonoids are mostly found in the pericarp layers or seed coats of the cereals and legumes (Shirley, 1998).

The antioxidant potential expressed as capacity of free radical scavenging ability is often assessed either by reaction with stable free radicals (e.g. ABTS radical scavenging) or by competition method using conventional UV/visible absorption spectrophotometry (e.g. ORAC assay) (Niki, 2011). The antioxidant capacity of the whole grain flours and cell wall preparations in terms of ferric reducing power (FRAP), ABTS radical scavenging and oxygen radical absorbance capacity (ORAC) are shown in Figure 4 (A-C). The FRAP and ABTS radical scavenging assays are based on the principle of single electron transfer from an antioxidant to an oxidant probe (ferric ions in the case of the FRAP assay and ABTS radical cation in the case of the ABTS assay) and measure the reducing ability of the antioxidant substrate (MacDonald-Wicks, Wood \& Garg, 2006). On the other hand, the ORAC assay is based on the principle of hydrogen atom transfer and measures the hydrogen donating ability of the antioxidant (MacDonald-Wicks, Wood \& Garg, 2006).

The trends in antioxidant properties of the whole grain and cell wall preparations were essentially similar to what was observed for their total phenolic contents. Whole grain flours of red sorghum, black eyed cowpea and Betchuana white cowpea had higher ferric reducing properties (Figure 4A), ABTS radical scavenging capacity (Figure 4B) and ORAC values (Figure 4C) than the other grain samples. Cell wall preparations of the grain samples had lower antioxidant properties than the whole grain samples. Overall, these results are in agreement with the generally observed trend that high phenolic content mostly results in high 
antioxidant activity. Reports have shown a positive correlation between total phenolic content and antioxidant activity of plant foods (Dlamini et al., 2007; Siatka \& Kašparová, 2010;).

The high antioxidant activities of the whole grain extract of red sorghum and Betchuana white cowpea could be due to their relatively higher phenolic contents. It may also be due to the presence of anthocyanins possibly because of their pigmentation. Anthocyanins are usually important components of dark-coloured or pigmented grains (Todd \& Vodkin, 1993; Mol et al., 1998). Some black sorghums which have no tannins but have high levels of anthocyanins, have been reported to have a relatively high antioxidant activity (Awika, 2003).

Figure 5 shows the inhibition of LDL oxidation capacity of the extracts from whole grain flours and cell wall preparations. For all grain samples, extracts from whole grain flours and cell wall preparations (at concentrations of 20 and $40 \mathrm{mg} / \mathrm{ml}$ ) inhibited oxidation of low density lipoprotein as shown by their lower TBARS absorbance units compared to the positive control (PC). Black eyed cowpea, white sorghum and brown teff showed a lower LDL oxidation inhibitory capacity (lower TBARS absorbance values) for the whole grain flour compared to the cell wall preparations. The other grain samples exhibited similar LDL oxidation inhibitory capacity for both whole grain and cell wall preparations. Overall, the results show that similar to the whole grain, extracts from the cell wall preparations also exhibit significant ability to inhibit LDL oxidation. Based on this result, it may be expected that in cereal- and legume-based foods, cell walls could make an important contribution to inhibition of LDL oxidation. Several studies have shown that phenolic compounds including flavonoids and phenolic acids have the capacity to inhibit oxidation of human LDL in vitro (Frankel et al., 1995; Lanningham-Foster et al., 1995). In this regard, phenolic-rich whole grain foods of the selected cereals and legumes used in this study that would be rich in 
dietary fibre and cell wall material could potentially be important for inhibition of LDL oxidation and the subsequent prevention of a number of free radical mediated diseases including atherogenesis and coronary heart diseases (Kanner et al., 1994).

The results of the protective effect on AAPH-induced oxidative DNA damage (Figures 6A and B) reveals better protection by the whole grain flour extracts compared to the extracts from cell wall preparations. Compared with the whole grain flour extracts, a higher concentration of the extracts from cell wall preparation was required to confer protection on the plasmid DNA against AAPH-induced oxidative damage (40 mg/ml for extracts from cell wall preparations compared with $0.133 \mathrm{mg} / \mathrm{ml}$ for extracts from whole grain flours). The observed better protection by the whole grain extracts may be due to the synergistic effects of the flavonoids and phenolic acids that are present therein unlike the extracts from cell wall preparations that contained mostly hydroxycinnamates. It has been reported that phenolic compounds could interact with themselves or with other phytochemicals synergistically to enhance their antioxidant activity (Jia, et al., 1998; Liu et al., 2000).

The phenolic acids and flavonoids identified in the extracts from cell wall preparations and whole grain flours in this study have attracted considerable attention due to their bioactive properties (Kadoma \& Fujisawa, 2008). These phenolics may be liberated from cell wall material by the action of micro-organisms in the colon and if absorbed, they could offer some potential health benefits such as ameliorating diseases such as cancer, diabetes and hypertension. Although these dietary phenolic compounds tend to be powerful antioxidants in vitro, there is growing evidence to suggest that the mechanism by which they may offer potential health benefits goes beyond mere antioxidant actions (Chiva-Blanch \& Visioli, 2012). Such mechanisms include anti-inflammatory activities, modulation of phase II enzymes and various other biomarkers of chronic diseases of lifestyle. In agreement with 
Chiva-Blanch and Visioli (2012), we believe that future research in this field should place more emphasis on investigating the effects of dietary phenolics on these biomarkers in clinical trials.

\section{ACKNOWLEDGEMENTS}

This research was supported by the South African National Research Foundation including the award of a post-doctoral fellowship for S.O. Salawu. Mr Alan Hall of the Electron Microscopy Unit of the University of Pretoria is gratefully acknowledged for technical assistance with scanning electron microscopy.

\section{REFERENCES}

AWIKA, J. M. 2003. Sorghum phenols as antioxidants. Ph.D Thesis, Texas A\&M University, College Station, TX, USA.

AWIKA, J.M., ROONEY, L.W., WU, X., PRIOR, R.L. and CISNEROS-ZEVALLOS, L. 2003. Screening methods to measure antioxidant activity of sorghum (Sorghum bicolor) and sorghum products. J. Agric. Food Chem. 51, 6657-6662.

BRILLOUET, J. and CARRE, B. 1983. Composition of cell walls from cotyledons of Pisum sativum, Vicia faba and Glycine max. Phytochemistry 22, 841-847.

BULTOSA, G., HALL, A.N. and TAYLOR J.R.N. 2002. Physico-chemical characterization of grain teff [Eragrostis teff (Zucc.) trotter] starch. Starch/Stärke 54, 461-468.

CAMPBELL, M.M. and ELLIS, B.E. 1992. Fungal elicitor-mediated responses in pine cell cultures: cell wall-bound phenolics. Phytochemistry 31, 737-742.

CHIVA-BLANCH, G. and VISIOLI, F. 2012. Polyphenols and health: Moving beyond antioxidants. J Berry Res. 2, 63-71. 
DE ASCENSAO, A.R.F.D.C. and DUBERY, I.A. 2003. Soluble and wall-bound phenolics and phenolic polymers in Musa acuminata roots exposed to elicitors from Fusarium oxysporum f. sp. cubense. Phytochemistry 63, 679-686.

DLAMINI, N.R., TAYLOR, J.R.N. and ROONEY, W.L. 2007. The effect of sorghum type and processing on the antioxidant activity of African sorghum-based foods. Food Chem. 105, 1412-1419.

DYKES, L. and ROONEY, L.W. 2006. Sorghum and millet phenols and antioxidants. J. Cereal Sci. 44, 236-251.

FRANKEL, E.N., WATERHOUSE, A.L. and TEISSEDRE, P.L. 1995. Principal phenolic phytochemicals in selected California wines and their antioxidant activity in inhibiting oxidation of human low-density lipoproteins. J. Agric. Food Chem. 43, 890-894.

GIAMI, S.Y. 2005. Influence of cowpea (Vigna unguiculata L. Walp) on protein quality and sensory properties of akara, a popular West African cowpea-based food. J. Sci. Food Agr. 85, 261-264.

HARBONE, J.B. and WILLIAMS, C.A. 2000. Advances in flavonoids research since 1992. Phytochemistry 55, 481-504.

IBRAHIM, R.K., DE LUCA, V., KHOUN, H., LATCHMIAN, L., BRISSON, L. and CHAREST, P.M. 1987. Enzymology and compartmentalization of polymethylated flavonol glucosides in Chrysosplenium americanum. Phytochemistry 26, 1237-1245.

JIA, Z.S., ZHOU, B., YANG, L., WU, L.M. and LIU, Z.L. 1998. Antioxidant synergism of tea polyphenols and a-tocopherol against free radical induced peroxidation of linoleic acid in solution. J. Chem. Soc., Perkin Trans. 2, 911-916.

KADOMA, Y. and FUJISAWA, S. 2008. A comparative study of the radical-scavenging activity of the phenolcarboxylic acids caffeic acid, p-coumaric acid, chlorogenic acid and ferulic acid, with or without 2-mercaptoethanol, a thiol, using the induction period method. Molecules 13, 2488-2499. 
KAMISAKA, S., TAKEDA, S., TAKAHASHI, K. and SHIBATA, K. 2006. Diferulic and ferulic acid in the cell wall of Avena coleoptiles - their relationships to mechanical properties of the cell wall. Physiol. Plantarum 78, 1-7.

KANNER, J., FRANKEL, E., GRANIT, R., GERMAN, B., \& KINSELLA, J. E. 1994. Natural antioxidants in grapes and wines. J. Agric. Food Chem. 42, 64-69.

KROON, P.A., FAULDS, C.B., RYDEN, P., ROBERTSON, J.A. and WILLIAMSON, G. 1997. Release of covalently bound ferulic acid from fiber in the human colon. J. Agric. Food Chem. 45, 661-667.

LANNINGHAM-FOSTER, L., CHEN, C., CHANCE, D.S. and LOO, G. 1995. Grape extract inhibits lipid peroxidation of human low density lipoprotein. Biol. Pharm. Bull. 18, 13471351.

LIU, Z.Q., MA, L.P., ZHOU, B., YANG, L. and LIU, Z.L. 2000. Antioxidative effects of green tea polyphenols on free radical initiated and photosensitized peroxidation of human low density lipoprotein. Chem. Phys. Lipids 106, 53-63.

MACDONALD-WICKS, L.K., WOOD, L.G. and GARG, M.L. 2006. Methodology for the determination of biological antioxidant capacity in vitro: A review. J. Sci. Food Agric. 86, 2046-2056.

MOL, J., GROTEWOLD, E. and KOES, R. 1998. How genes paint flowers and seeds. Trends Plant Sci. 3, 212-217.

NATIONAL ACADEMY OF SCIENCE. 1975. Population and food-crucial issues. National Academy of Science, Washington, D.C.

NATIONAL RESEARCH COUNCIL. 1996. Lost Crops of Africa. Vol. 1: Grains. Washington DC: National Academic Press.

NIELSEN, S.S., OHLER, T.A. and MITCHELL, C.A. 1997. Cowpea leaves for human consumption: production, utilization and nutrient composition. In: Singh, B.B., Moham Raj, D.R., Dashiell, K.E., Jackai, L.E.N. (Eds.), Advances in Cowpea Research. Co-publication of 
International Institute of Tropical Agriculture (IITA) and Japan International Research Centre for Agricultural Science (JIRCAS), IITA, Ibadan, Nigeria, (pp. 326-332).

NIKI, E. 2011. Antioxidant capacity: Which capacity and how to assess it? J Berry Res. 1, 169-176.

OU, B., HUANG, D, HAMPSCH-WOODILL, M., FLANAGAN, J.A. and DEEMER, E.K. 2002. Analysis of antioxidant activities of common vegetables employing oxygen radical absorbance capacity (ORAC) and ferric reducing antioxidant power (FRAP) assays: a comparative study. J. Agric. Food Chem. 50, 3122-3128.

OYAIZU, M. 1986. Studies on products of browning reaction prepared from glucoseamine. Japanese J. Nutri. 44, 307-314.

ROBBINS, R.J. 2003. Phenolic acids in foods: an overview of analytical methodology. J. Agric. Food Chem. 51, 2866-2887.

SALUNKHE, D.K. 1982. Legumes in human nutrition. Current status and future research needs. Curr. Sci. 51:387-394.

SHELEMBE, J.S., CROMARTY, D., BESTER, M.J., MINNAAR, A. and DUODU, K.G. 2012. Characterization of phenolic acids, flavonoids, proanthocyanidins and antioxidant activity of water extracts from seed coats of marama bean [Tylosema esculentum] - an underutilised food legume. Int. J Food Sci. Tech. 47, 648-655.

SHIRLEY, B.W. 1998. Flavonoids in seeds and grains: physiological function, agronomic importance and genetic biosynthesis. Seed Sci. Res. 8, 415-422.

SIATKA, T. and KAŠPAROVÁ, M. 2010. Seasonal variation in total phenolic and flavonoid contents and DPPH scavenging activity of Bellis perennis L. flowers. Molecules, 15, 94509461.

SINGLETON, V.L. and ROSSI, J.A. 1965. Colorimetry of total phenolics with phosphomolybdicphosphotungstic acid reagents. Am. J. Enol. Vitic. 16, 144-158. 
TAYLOR, J.R.N. and DEWAR, J. 2000. Fermented products: Beverages and porridges. In 'Sorghum: Origin, History, Technology, and Production', (C. Wayne Smith and R.A. Frederiksen, eds), John Wiley \& Sons, New York (pp. 751-795).

TODD, J.J. and VODKIN, L.O. 1993. Pigmented soybean (Glycine max) seed coats accumulate proanthocyanidins during development. Plant Physiol. 102, 663-670.

VITAGLIONE, P., NAPOLITANO, A. and FOGLIANO, V. 2008. Cereal dietary fibre: A natural functional ingredient to deliver phenolic compounds into the gut. Trends Food Sci. Tech. 19, 451-463.

WEI, M., HORI, T.A., ICHIHARA, T., WANIBUCHI, H., MORIMURA, K., KANG, J.S., PUATANACHOKCHAI, R. and FUKUSHIMA, S. 2006. Existence of no-observed effect levels for 2-amino-3, 8-dimethylimidazo [4,5-f]quinoxaline on hepatic preneoplastic lesion development in BN rats. Cancer Letters 231, 304-308.

ZHISHEN, J., MENGCHENG, T. and JIANMING, W. 1999. The determination of flavonoid contents in mulberry and their scavenging effects on superoxide radicals. Food Chem. 64, 555-559. 


\section{FIGURE CAPTIONS}

Figure 1 (A-L): The scanning electron micrographs of the whole grain flours (A, C, E, G, I and $\mathrm{K})$ and cell wall preparations $(\mathrm{B}, \mathrm{D}, \mathrm{F}, \mathrm{H}, \mathrm{J}$ and $\mathrm{L})$ of Brown teff (A-B); White sorghum (C-D); White teff (E-F); Red sorghum(G-H); Black-eyed cowpea (I-J); Betchuana white cowpea (K-L). 1 - Chunks of material; 2 - Cell wall fragment; 3 - Remnants of starch granules and protein bodies; 4 - Material with empty cells (indicated with arrows)

Figure 2: A) Total phenolics and B) Total flavonoids of whole grain flour and cell wall preparations of cereals and legumes. Error bars represent standard deviations. Graph bars with the same letters are not significantly different $(\mathrm{p}<0.05)$. RS - red sorghum, WS - white sorghum, BT - brown teff, WT - white teff, BW - Betchuana white cowpea, BEC - Black eye cowpea

Figure 3: HPLC chromatograms of extracts from whole grain flours and cell wall preparations of selected cereals and legumes. RS - red sorghum, WS - white sorghum, BT brown teff, WT - white teff, BEC - Black eye cowpea, BW - Betchuana white cowpea 1 - Catechin; 2 - p-Hydroxybenzoic acid; 3 - Caffeic acid; 4 - p-Coumaric acid; 5 - Ferulic acid; 6 - Taxifolin; 7 - Naringenin; 8 - Quercetin; 9 - Luteolin; 10 - Cinnamic acid; 11 Apigenin

Chromatograms for sorghum and teff samples are given at $280 \mathrm{~nm}$ and chromatograms for cowpea samples are given at $330 \mathrm{~nm}$

Figure 4: A) Reducing power, B) ABTS radical scavenging activity and C) ORAC values of whole grain flour and cell wall preparations of cereals and legumes. Error bars represent 
standard deviations. Graph bars with the same letters are not significantly different $(\mathrm{p}<$ 0.05). RS - red sorghum, WS - white sorghum, BT - brown teff, WT - white teff, BW Betchuana white cowpea, BEC - Black eye cowpea

Figure 5: Effect of extracts from whole grain flour and cell wall preparations of cereals and legumes on copper-catalyzed LDL oxidation. Error bars represent standard deviations. Graph bars with the same letters are not significantly different $(\mathrm{p}<0.05)$.

$\mathrm{NC}$ - negative control (LDL), PC - positive control $\left(\mathrm{LDL}+\mathrm{Cu}^{2+}\right)$, Trolox - Trolox at 75 $\mu \mathrm{M}+\mathrm{LDL}, \mathrm{RS}$ - red sorghum, WS - white sorghum, BT - brown teff, WT - white teff, BW Betchuana white cowpea, BEC - Black eye cowpea

40,20 - Concentration of extracts at 40 and $20 \mathrm{mg} / \mathrm{ml}$

Figure 6: Effect of extracts from A) whole grain flour (at $0.133 \mathrm{mg} / \mathrm{ml}$ ) and B) cell wall preparations (at $40 \mathrm{mg} / \mathrm{ml}$ ) of cereals and legumes on AAPH-induced oxidative supercoiled plasmid pBR 322 DNA damage. Error bars represent standard deviations. Graph bars with the same letters are not significantly different $(\mathrm{p}<0.05)$. Trolox at $2 \mu \mathrm{M}$. RS - red sorghum, WS - white sorghum, BT - brown teff, WT - white teff, BW - Betchuana white cowpea, BEC - Black eye cowpea 
Table 1

PHENOLIC ACID AND FLAVONOID CONTENTS (MG/100 G) OF EXTRACTS FROM WHOLE GRAIN FLOUR AND CELL WALL PREPARATIONS OF SELECTED CEREALS AND LEGUMES

\begin{tabular}{|c|c|c|c|c|c|c|}
\hline Compound & $\mathrm{RS}$ & WS & BT & WT & $\mathrm{BEC}$ & BW \\
\hline \multicolumn{7}{|c|}{ WHOLE GRAIN EXTRACTS } \\
\hline Caffeic acid & $2.43 \pm 0.39$ & ND & ND & ND & ND & ND \\
\hline p-Coumaric acid & $0.72 \pm 0.06$ & $0.40 \pm 0.03$ & $1.56 \pm 0.37$ & $0.87 \pm 0.10$ & $7.89 \pm 0.31$ & $4.87 \pm 0.08$ \\
\hline Ferulic acid & trace & $0.89 \pm 0.17$ & $5.38 \pm 0.17$ & $2.52 \pm 0.40$ & $6.10 \pm 1.01$ & $2.12 \pm 0.41$ \\
\hline Catechin & $23.63 \pm 4.94$ & ND & ND & ND & ND & ND \\
\hline Naringenin & $0.99 \pm 0.28$ & $0.68 \pm 0.09$ & ND & ND & $3.61 \pm 0.81$ & ND \\
\hline Apigenin & $14.34 \pm 0.62$ & $28.92 \pm 4.83$ & ND & $3.14 \pm 0.38$ & $9.53 \pm 0.81$ & $2.11 \pm 0.12$ \\
\hline Luteolin & ND & $9.91 \pm 2.04$ & ND & ND & $4.03 \pm 0.95$ & ND \\
\hline p-Hydroxybenzoic acid & ND & ND & $59.75 \pm 3.03$ & $34.44 \pm 2.37$ & ND & ND \\
\hline Quercetin & ND & ND & ND & ND & $30.72 \pm 3.28$ & $4.54 \pm 0.73$ \\
\hline Taxifolin & ND & ND & ND & ND & $5.21 \pm 0.58$ & $4.54 \pm 0.40$ \\
\hline Cinnamic acid & ND & ND & ND & ND & ND & $2.43 \pm 0.18$ \\
\hline \multicolumn{7}{|c|}{ CELL WALL EXTRACTS } \\
\hline$\overline{\mathrm{p} \text {-Coumaric acid }}$ & $23.59 \pm 0.57$ & $15.18 \pm 2.50$ & $1.17 \pm 0.00$ & $0.69 \pm 0.07$ & $0.15 \pm 0.03$ & $0.50 \pm 0.01$ \\
\hline Ferulic acid & $128.94 \pm 0.76$ & $37.87 \pm 5.33$ & $14.16 \pm 0.18$ & $39.40 \pm 0.76$ & $1.39 \pm 0.11$ & $0.45 \pm 0.05$ \\
\hline Catechin & ND & ND & $\mathrm{ND}$ & ND & trace & $33.60 \pm 4.21$ \\
\hline Naringenin & ND & ND & ND & ND & ND & ND \\
\hline Apigenin & ND & ND & ND & trace & ND & ND \\
\hline Luteolin & ND & ND & $5.17 \pm 0.64$ & $3.24 \pm 0.15$ & ND & ND \\
\hline p-Hydroxybenzoic acid & ND & ND & trace & trace & ND & ND \\
\hline Quercetin & ND & ND & $1.50 \pm 0.02$ & $24.51 \pm 2.92$ & ND & ND \\
\hline Taxifolin & ND & ND & ND & ND & ND & ND \\
\hline Cinnamic acid & ND & ND & ND & ND & ND & trace \\
\hline
\end{tabular}

Values are presented as Mean $\pm \mathrm{SD}(\mathrm{n}=4)$.

ND - not detected; RS-Red sorghum; WS-White sorghum; BT-Brown teff; WT-White teff; BEC-Black eyed pea; BW-Betchuana white 


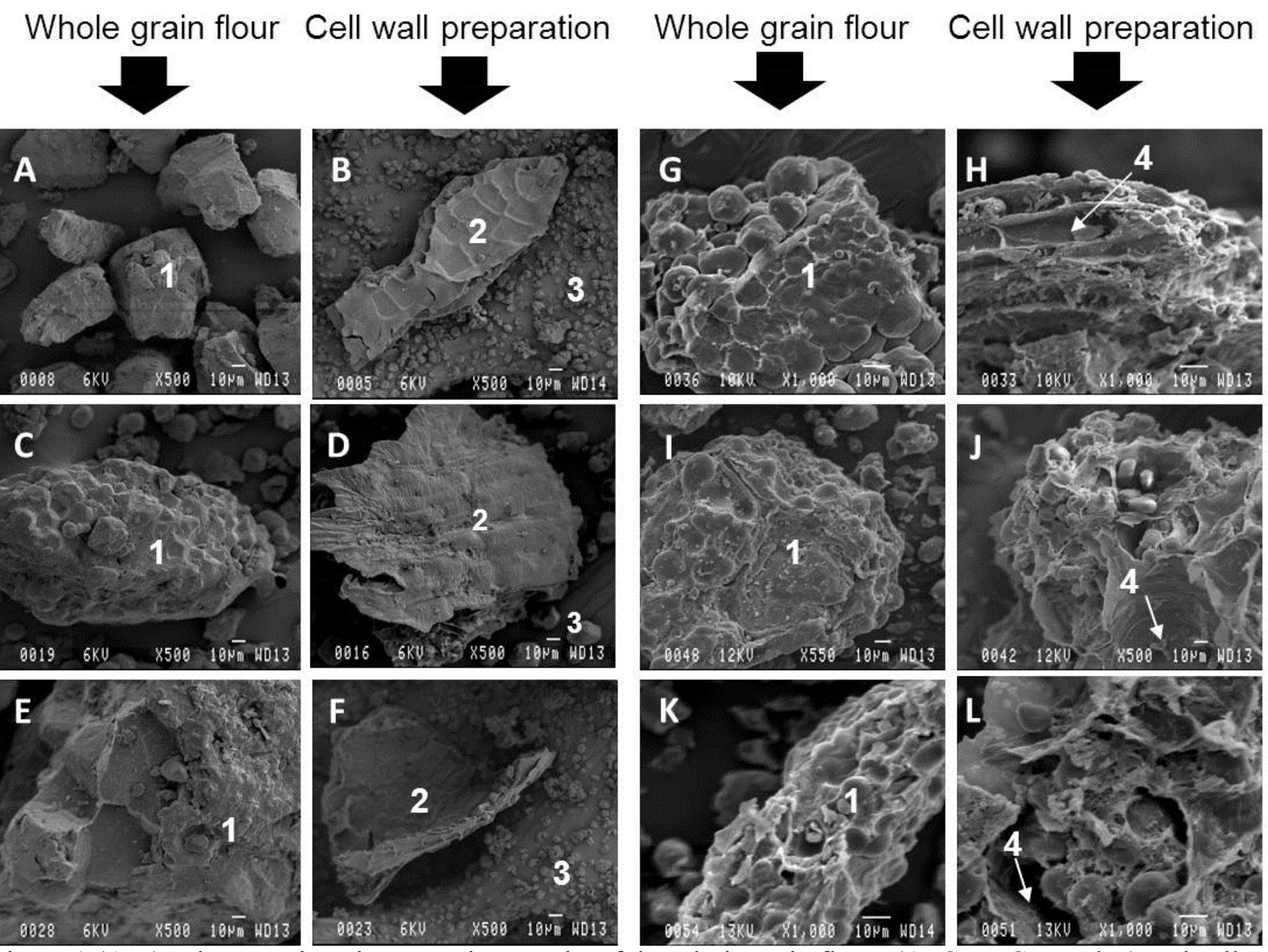

Figure 1 (A-L): The scanning electron micrographs of the whole grain flours (A, C, E, G, I and K) and cell wall preparations (B, D, F, $\mathrm{H}, \mathrm{J}$ and L) of Brown teff (A-B); White sorghum (C-D); White teff (E-F); Red sorghum(G-H); Black-eyed cowpea (I-J); Betchuana white cowpea (K-L). 1 - Chunks of material; 2 - Cell wall fragment; 3 - Remnants of starch granules and protein bodies; 4 - Material with empty cells (indicated with arrows) 

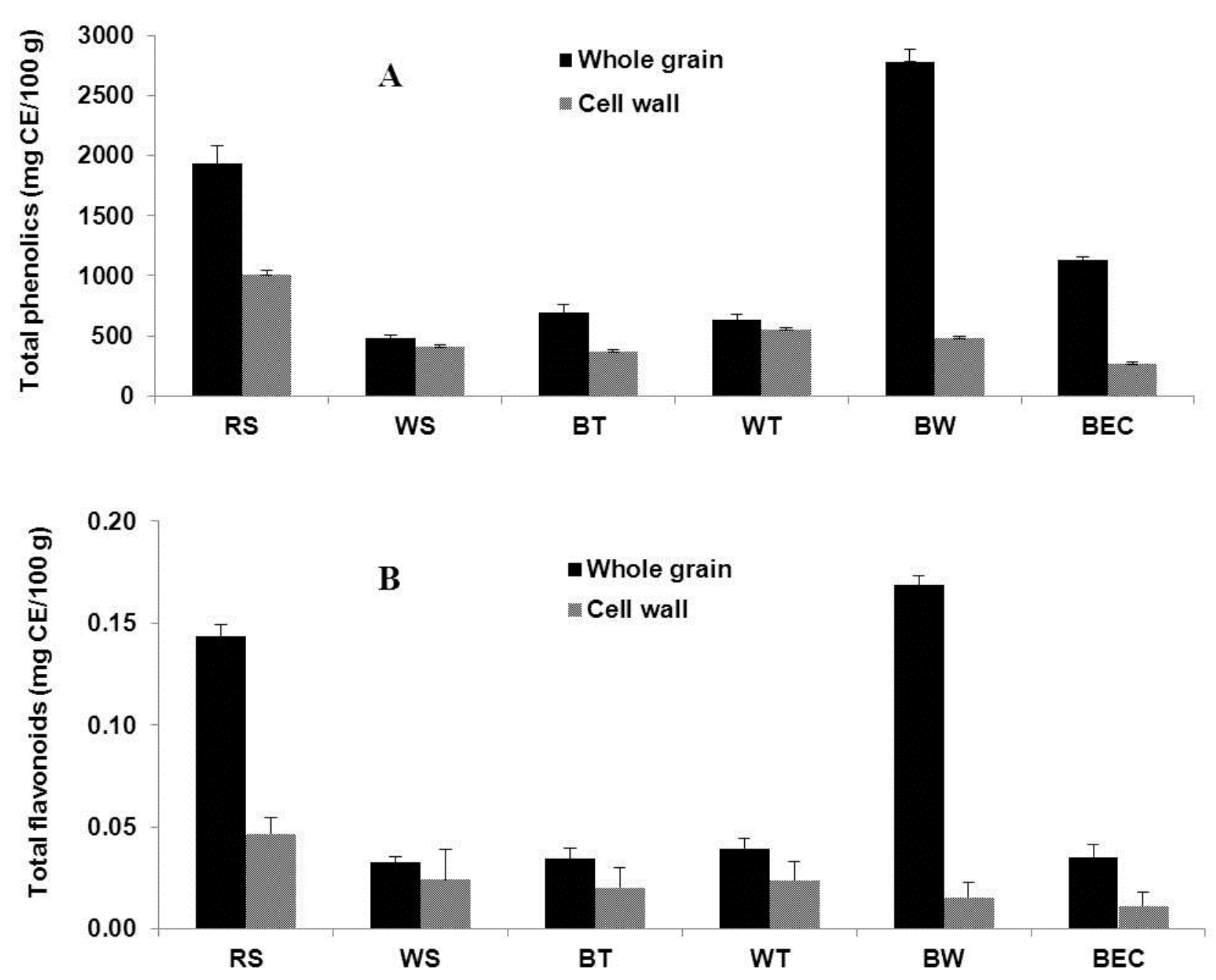

Figure 2: A) Total phenolics and B) Total flavonoids of whole grain flour and cell wall preparations of cereals and legumes. Error bars represent standard deviations. Graph bars with the same letters are not significantly different $(\mathrm{p}<0.05)$. RS - red sorghum, WS white sorghum, BT - brown teff, WT - white teff, BW - Betchuana white cowpea, BEC - Black eye cowpea 


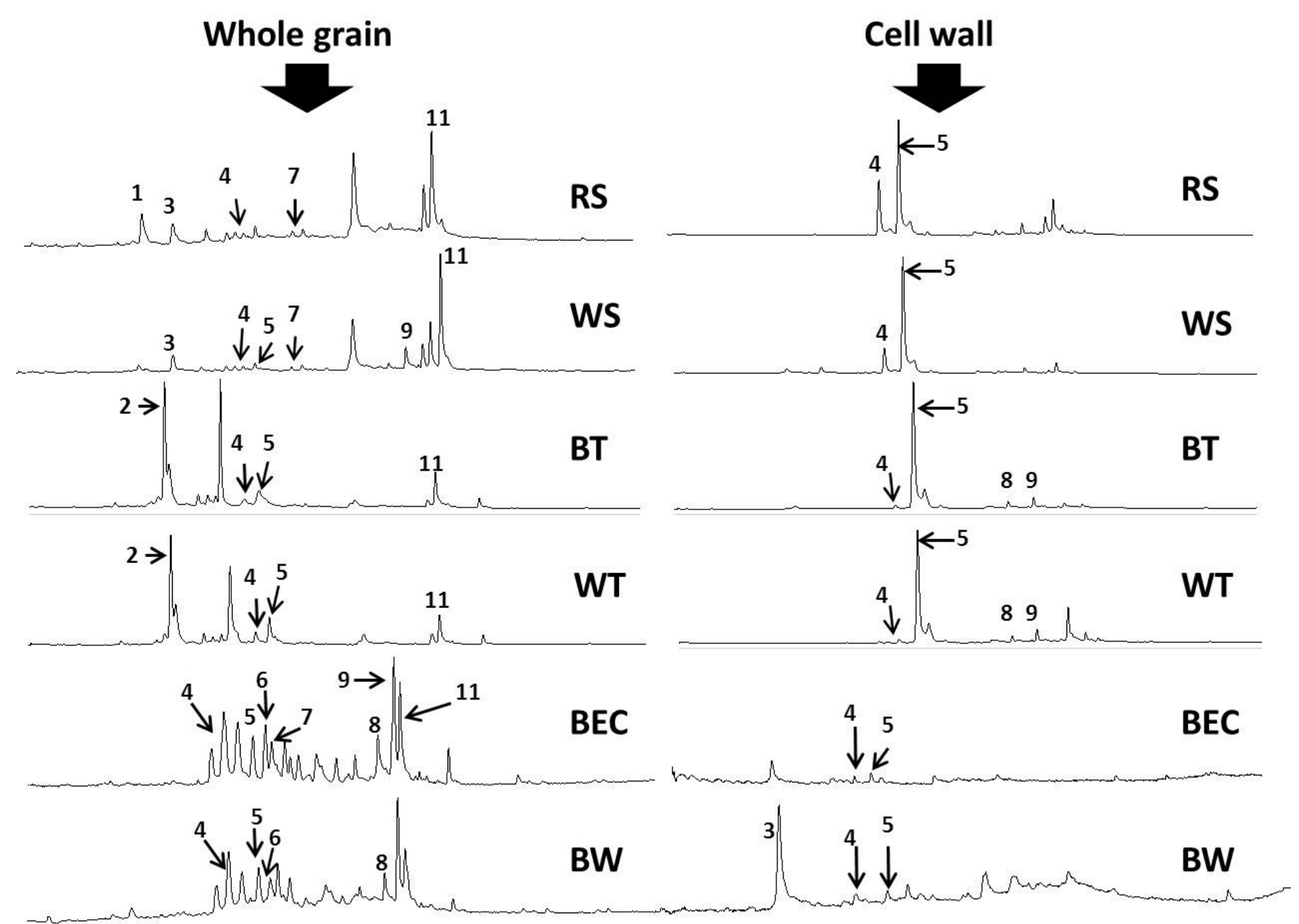

Figure 3: HPLC chromatograms of extracts from whole grain flours and cell wall preparations of selected cereals and legumes. RS red sorghum, WS - white sorghum, BT - brown teff, WT - white teff, BEC - Black eye cowpea, BW - Betchuana white cowpea 1 - Catechin; 2 - p-Hydroxybenzoic acid; 3 - Caffeic acid; 4 - p-Coumaric acid; 5 - Ferulic acid; 6 - Taxifolin; 7 - Naringenin; 8 Quercetin; 9 - Luteolin; 10 - Cinnamic acid; 11 - Apigenin 

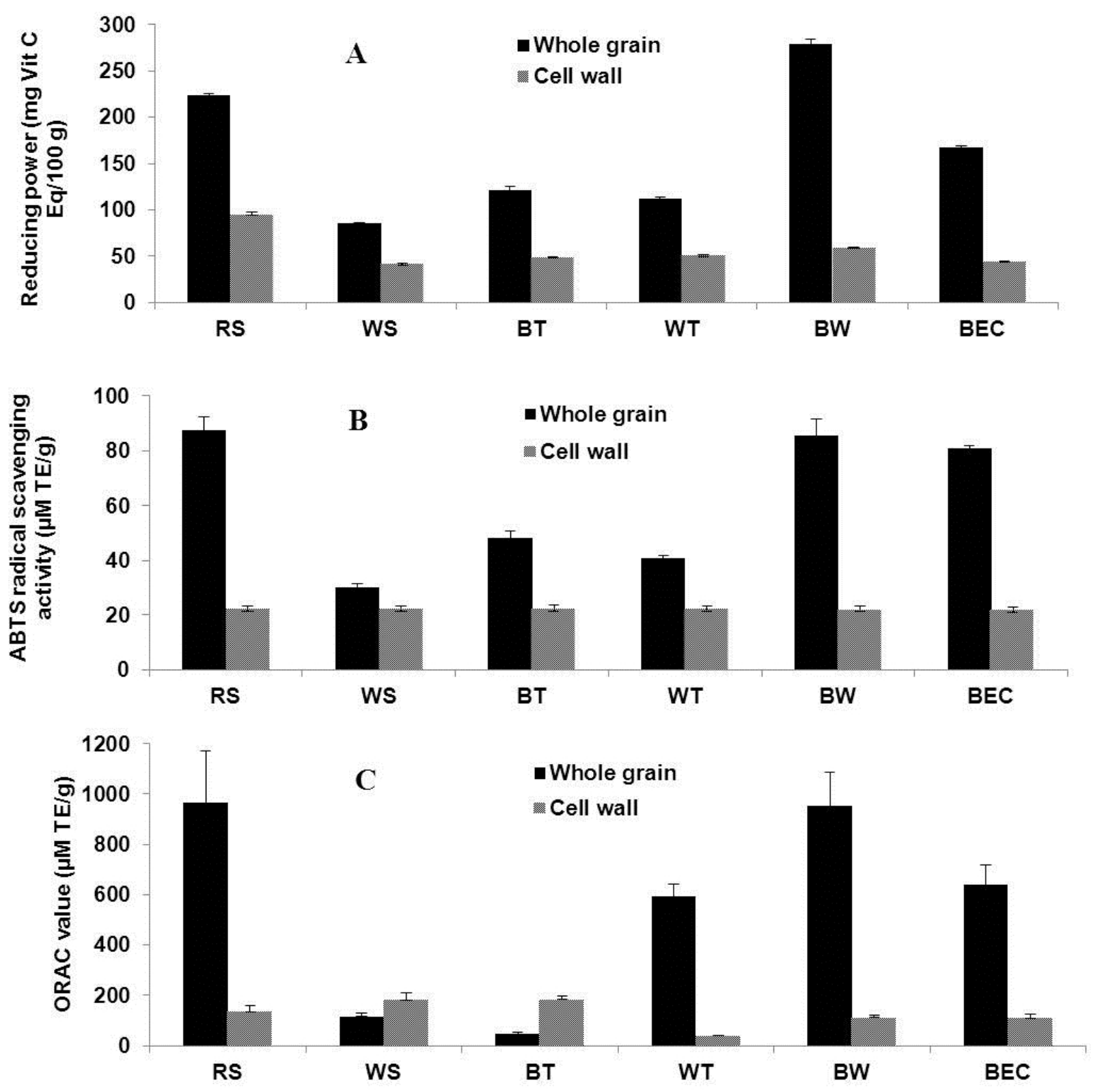

Figure 4: A) Reducing power, B) ABTS radical scavenging activity and C) ORAC values of whole grain flour and cell wall preparations of cereals and legumes. Error bars represent standard deviations. Graph bars with the same letters are not significantly different $(\mathrm{p}<0.05)$. RS - red sorghum, WS - white sorghum, BT - brown teff, WT - white teff, BW - Betchuana white cowpea, BEC - Black eye cowpea 


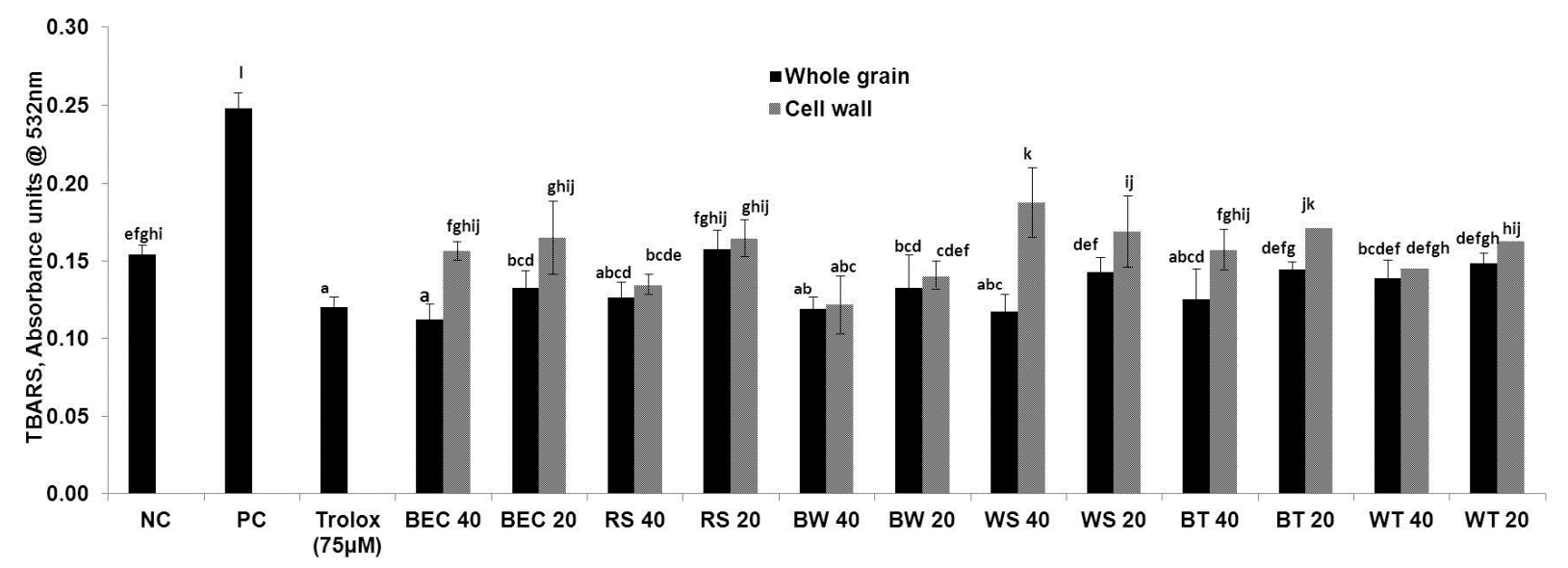

Figure 5: Effect of extracts from whole grain flour and cell wall preparations of cereals and legumes on copper-catalyzed LDL oxidation. Error bars represent standard deviations. Graph bars with the same letters are not significantly different $(\mathrm{p}<0.05)$.

$\mathrm{NC}$ - negative control (LDL), PC - positive control $\left(\mathrm{LDL}+\mathrm{Cu}^{2+}\right)$, Trolox - Trolox at $75 \mu \mathrm{M}+\mathrm{LDL}$, RS - red sorghum, WS - white sorghum, BT - brown teff, WT - white teff, BW - Betchuana white cowpea, BEC - Black eye cowpea

40,20 - Concentration of extracts at 40 and $20 \mathrm{mg} / \mathrm{ml}$ 

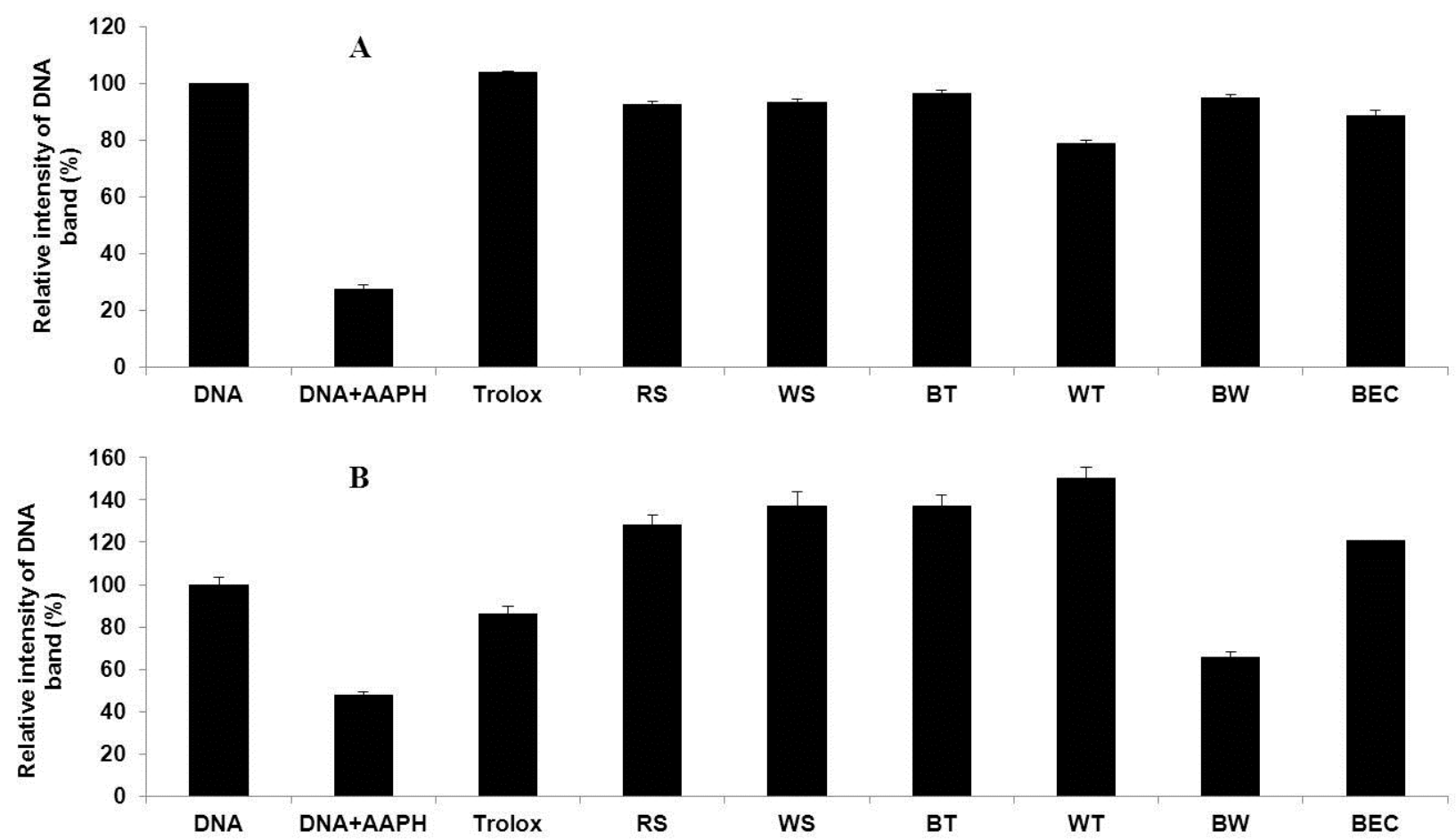

Figure 6: Effect of extracts from A) whole grain flour (at $0.133 \mathrm{mg} / \mathrm{ml}$ ) and B) cell wall preparations (at $40 \mathrm{mg} / \mathrm{ml}$ ) of cereals and legumes on AAPH-induced oxidative supercoiled plasmid pBR 322 DNA damage. Error bars represent standard deviations. Graph bars with the same letters are not significantly different $(\mathrm{p}<0.05)$. Trolox at $2 \mu \mathrm{M}$. RS - red sorghum, WS white sorghum, BT - brown teff, WT - white teff, BW - Betchuana white cowpea, BEC - Black eye cowpea 